\title{
Anabolic steroid- and exercise-induced cardiac stress protein (HSP72) in the rat
}

\author{
W. Lunz¹, E.C. Oliveira², \\ M.T.D. Neves ${ }^{3}$, E.P.B. Fontes ${ }^{4}$, \\ C.M.G.C. Dias ${ }^{5}$ and \\ A.J. Natali ${ }^{2}$
}

\author{
1D epartamento de Nutrição e Saúde, 2D epartamento de Educação Física, \\ ${ }^{3}$ Departamento de Veterinária, ${ }^{4} \mathrm{D}$ epartamento de Bioquímica e Biologia M olecular, \\ ${ }^{5}$ Departamento de Biologia Animal, Universidade Federal de Viçosa, Viçosa, MG, \\ Brasil
}

\section{Correspondence \\ A.J. Natali \\ Departamento de Educação Física Universidade Federal de Viçosa \\ Av. P.H. Rolfs, $s / n$ \\ 36570-000 Viçosa, MG \\ Brasil \\ Fax: + 55-31-3899-2249 \\ E-mail: anatali@ufv.br \\ Presented at the LVII Annual Meeting of SBPC, Fortaleza, CE, Brazil, July 17-22, 2005. \\ W. Lunz was supported by a scientific training grant from PIBIC program of CN Pq.}

Received September 20, 2005 Accepted April 26, 2006

\section{Abstract}

The present study investigated the effects of exercise and anabolicandrogenic steroids on cardiac HSP72 expression. Male Wistar rats were divided into experimental groups: nandrolone exercise (NE, $\mathrm{N}=$ 6), control exercise ( $\mathrm{CE}, \mathrm{N}=6$ ), nandrolone sedentary ( $N S, N=6$ ), and control sedentary ( $\mathrm{CS}, \mathrm{N}=6)$. Animals in the $\mathrm{NE}$ and NS groups received a weekly intramuscular injection $(6.5 \mathrm{mg} / \mathrm{kg}$ of body weight $)$ of nandrolone decanoate, while those in the CS and CE groups received mineral oil as vehicle. Animals in the NE and CE groups were submitted to a progressive running program on a treadmill, for 8 weeks. Fragments of the left ventricle were collected at sacrifice and the relative immunoblot contents of HSP72 were determined. Heart weight to body weight ratio was higher in exercised than in sedentary animals $(\mathrm{P}<0.05,4.65 \pm 0.38$ vs $4.20 \pm 0.47 \mathrm{mg} / \mathrm{g}$, respectively), independently of nandrolone, and in nandrolone-treated than untreated animals $(\mathrm{P}<0.05,4.68 \pm 0.47 v s 4.18 \pm 0.32 \mathrm{mg} / \mathrm{g}$, respectively), independently of exercise. Cardiac HSP72 accumulation was higher in exercised than in sedentary animals $(\mathrm{P}<0.05,677.16 \pm$ 129.14 vs $246.24 \pm 46.30$ relative unit, respectively), independently of nandrolone, but not different between nandrolone-treated and untreated animals $(\mathrm{P}>0.05,560.88 \pm 127.53$ vs $362.52 \pm 95.97$ relative unit, respectively) independently of exercise. Exercise-induced HSP72 expression was not affected by nandrolone. These levels of HSP72 expression in response to nandrolone administration suggest either a low intracellular stress or a possible less protection to the myocardium.

Testosterone and several synthetic derivatives of sexual steroids, the anabolicandrogenic steroids (AASs), are known to stimulate muscle protein synthesis and enlargement (1) and have been used in sports in order to increase muscle size and performance. However, AAS use may cause adverse effects on the cardiac muscle such as disintegration of the functional syncytium (2), cardiac rupture and deterioration of the
Key words - Physical activity - Nandrolone - Myocardium - Heat shock protein ..................... cardiac function (3) and cell death signaling (4) and has been associated with myocardial infarction, cardiomyopathy and sudden death (5).

The exposure of cells to various sublethal stresses results in an adaptive increase in the inducible member of the $70-\mathrm{kDa}$ family of heat shock proteins (HSP70), the $72-\mathrm{kDa}$ HSP72, which confers cellular resistance to a variety of stresses (6). Exercise is also a 
type of stressor that increases the content of HSP72 in mammalian cardiac muscle $(7,8)$ and some evidence indicates that exerciseinduced HSP72 plays a protective role in the mammalian heart against stresses (9).

One would expect that the deleterious effects of the AASs on the heart should be reflected by an increased HSP72 expression and, conversely, a possible inhibition of HSP72 expression in response to the use of AASs would explain, at least in part, the deleterious effects of this synthetic hormonal agent on the myocardium. Furthermore, it is not known whether the interaction of the stresses imposed on the heart by AASs and exercise training would affect HSP72 expression. Therefore, we investigated the effects of administering nandrolone decanoate to sedentary or chronically exercised rats on the induction of cardiac HSP72 expression.

Adult male Wistar rats bred in the animal facilities of the Federal University of Viçosa (Viçosa, MG, Brazil) were randomly assigned to one of four groups: nandrolone exercise ( $\mathrm{NE}, \mathrm{N}=6$ ), control exercise ( $\mathrm{CE}$, $N=6$ ), nandrolone sedentary ( $N S, N=6$ ), and control sedentary $(\mathrm{CS}, \mathrm{N}=6)$. Animals were caged collectively in groups of 6 , maintained on a 12:12-h dark-light cycle at $24 \pm$ $1^{\circ} \mathrm{C}$, with free access to food and water. All animals were weighed weekly and the sedentary ones were handled at the same time as the exercise-trained animals performed their training sessions. All experimental procedures employed were in accordance with nationally accepted ethical principles concerning the care and use of laboratory animals (10).

Animals in the NE and NS groups received a weekly intramuscular injection (6.5 $\mathrm{mg} / \mathrm{kg}$ body weight) of nandrolone decanoate (Deca Durabolin, Organon do Brasil, São Paulo, SP, Brazil) into the right or left hindlimb and those in the CS and CE groups received a weekly injection of the same amount of mineral oil, the vehicle for the androgenic steroid.
Animals in the NE and CE groups were submitted to a progressive exercise training program on a treadmill, 5 days/week, for 8 weeks (adapted from Noble et al., 9). Initially, rats ran at $17 \mathrm{~m} / \mathrm{min}, 0 \%$ grade for $15 \mathrm{~min}$, which was increased by $5 \mathrm{~min} /$ day until the animals were running for $60 \mathrm{~min} / \mathrm{session}$ by the end of week 2 . At weeks 3 and 4 , rats ran at $17 \mathrm{~m} / \mathrm{min}$ up a $10 \%$ grade for $60 \mathrm{~min} / \mathrm{session}$. At week 5, daily training session consisted of a warm-up of $8 \mathrm{~min}$ at $17 \mathrm{~m} / \mathrm{min}$, followed by $45 \mathrm{~min}$ at $20 \mathrm{~m} / \mathrm{min}$, and finished with a $5 \mathrm{~min}$ warm-down at $17 \mathrm{~m} / \mathrm{min}$. At weeks 6, 7, and 8, each training session consisted of a warm-up of $8 \mathrm{~min}$ at $20 \mathrm{~m} / \mathrm{min}$, followed by $45 \mathrm{~min}$ at 23 $\mathrm{m} / \mathrm{min}$ and ending with a 5-min warm-down at $18 \mathrm{~m} / \mathrm{min}$.

Five days after the completion of the last exercise training all animals were euthanized by cervical dislocation after anesthesia. The heart was rapidly removed and extraneous tissue was dissected away. The heart was then blotted dry and weighed. The left ventricle was separated from the atria, right ventricle and interventricular septum and left ventricle fragments were collected, immediately frozen in liquid nitrogen, and stored at $-80^{\circ} \mathrm{C}$ until subsequent analysis.

Proteins were separated by SDS-PAGE and immunoblotted with a monoclonal HSP70 antibody. Frozen samples of cardiac muscle were crushed in liquid nitrogen and $60 \mu \mathrm{g}$ of the powder was homogenized with $1200 \mu \mathrm{L}$ of extraction buffer $(600 \mathrm{mM} \mathrm{NaCl}$, $15 \mathrm{mM}$ Tris-HCL, $1 \mathrm{mM}$ PMSF, $\mathrm{pH}$ 7.5). After 5-min incubation at $0^{\circ} \mathrm{C}$, cell debris were removed by centrifugation at $14,000 \mathrm{~g}$ and $4^{\circ} \mathrm{C}$ for $20 \mathrm{~min}$ and the supernatant was stored at $-20^{\circ} \mathrm{C}$. Muscle protein concentration was determined as described by Bradford (11) and PAGE was performed as described by Laemmli (12). The protein extract was incubated for $5 \mathrm{~min}$ at $100^{\circ} \mathrm{C}$ in sample buffer (10\% (v/v) glycerol, $2.3 \%(\mathrm{w} / \mathrm{v})$ SDS, $0.25 \%(\mathrm{w} / \mathrm{v})$ bromophenol blue, $5 \%(\mathrm{v} / \mathrm{v}) 2-$ mercaptoethanol, and $0.0625 \mathrm{M}$ Tris-HCl, $\mathrm{pH}$ 6.8) before being loaded onto the wells. 
Electrophoresis was conducted for $\sim 16 \mathrm{~h}$ at $48 \mathrm{~V}$ in running buffer $(0.025 \mathrm{M}$ Tris- $\mathrm{HCl}$, $0.2 \mathrm{M}$ glycine, $1 \mathrm{mM}$ EDTA, and $3.5 \mathrm{mM}$ SDS). Proteins were transferred from the gels to nitrocellulose membranes using a blot apparatus (Bio-Rad Laboratories, Hercules, CA, USA) according to manufacturer instructions. The membranes were blocked with 35 (w/v) casein (non-fat dry milk, Bio$\mathrm{Rad}$ ) in TBST [0.01 M Tris-HCl, pH 7.6, 1.5 $\mathrm{mM} \mathrm{NaCl}, 0.1 \%$ (v/v) Tween-20] for $1 \mathrm{~h}$. HSP72 was detected with monoclonal antiHSP70 antibody (Sigma, St. Louis, MO, USA), at 1:5,000 dilution, followed by an alkaline phosphatase-conjugated secondary antibody (Anti-Mouse IgG, Sigma) at 1: 10,000 dilution. After extensive washing with TBST, the membrane was incubated in enzyme buffer (0.1 M Tris-HCl, pH 9.8, 0.1 M $\mathrm{NaCl}, 0.5 \mathrm{M} \mathrm{MgCl}_{2}$ ) for $10 \mathrm{~min}$. Alkaline phosphatase was detected using p-nitro blue tetrazolium and 5-bromo-4-chloro-3-indolylphosphate (Gibco-BRL, Carlsbad, CA, USA). The relative protein content was determined using a Personal Densitometer equipped with Image Quant, version 5.2 (Molecular Dinamics, USA).

Neither initial and final body weight (BW) nor heart weight (HW) to BW ratio (HW/ BW) were statistically different between groups (Table 1). Nevertheless, the exercised animals exhibited a higher (two-way ANOVA, $\mathrm{P}<0.05)$ HW/BW compared with sedentary animals (mean \pm SEM; $4.65 \pm$ 0.10 vs $4.20 \pm 0.11 \mathrm{mg} / \mathrm{g}$, respectively), independently of receiving nandrolone. This indicates that the training regime induced cardiac hypertrophy, a physiological adaptation also reported by others (13). Likewise, the nandrolone-treated rats showed a higher $(\mathrm{P}<0.05)$ HW/BW than untreated animals $(4.68 \pm 0.10 v s 4.18 \pm 0.11 \mathrm{mg} / \mathrm{g}$, respectively), independent of the exercise training. This means that the administration of nandrolone also promoted cardiac hypertrophy. In fact, cardiac hypertrophy in response to anabolic steroids has been reported in sedentary and exercised rats $(14,15)$.

We demonstrated that exercised animals exhibited a greater (two-way ANOVA, P < 0.05 ) accumulation of HSP72 in the cardiac muscle compared to sedentary animals (mean \pm SEM; $677.16 \pm 129.14$ vs $246.24 \pm 46.30$ relative unit, respectively), independently of the nandrolone administration. However, the accumulation of HSP72 was not statistically different $(\mathrm{P}>0.05)$ between nandrolonetreated and untreated animals (560.88 \pm 127.53 vs $362.52 \pm 95.97$ relative unit, respectively) independently of exercise, although it promoted cardiac hypertrophy. HSP73 was expressed similarly in all animals regardless of the experimental group and was not affected by exercise training as was expected for a constitutive HSP70 family member (Figure 1).

Table 1. Effect of nandrolone and exercise on body weight and heart weight to body weight ratio (HW/BW).

\begin{tabular}{lccc}
\hline Groups & Initial body weight & Final body weight & HW/BW \\
\hline Nandrolone sedentary & $360.00 \pm 28.28$ & $375.00 \pm 30.80$ & $4.47 \pm 0.50$ \\
Control sedentary & $363.33 \pm 29.44$ & $395.00 \pm 22.80$ & $3.94 \pm 0.23$ \\
Nandrolone exercise & $360.00 \pm 28.28$ & $387.00 \pm 22.30$ & $4.89 \pm 0.37$ \\
Control exercise & $363.34 \pm 30.11$ & $417.00 \pm 17.90$ & $4.41 \pm 0.22$ \\
\hline
\end{tabular}

Data are reported as means \pm SEM for 6 rats in each group. Rats received either 6.5 $\mathrm{mg} / \mathrm{kg}$ nandrolone decanoate or vehicle weekly and were submitted to exercise for 8 weeks or were sedentary. No difference between groups was observed (two-way ANOVA, $P>0.05$.

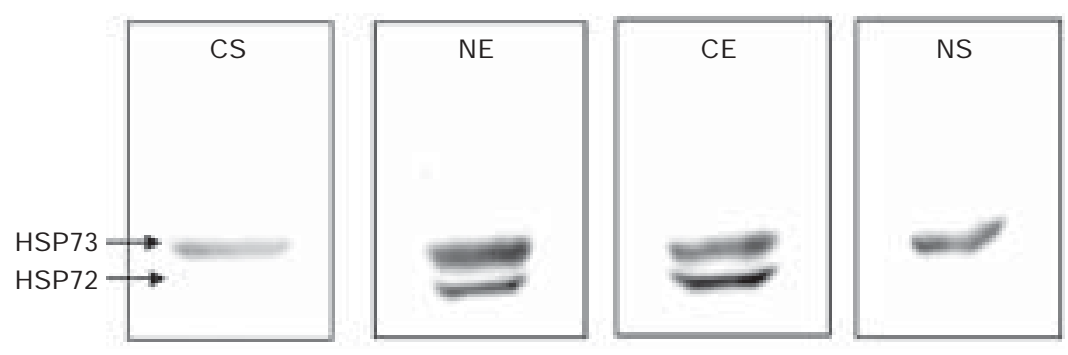

Figure 1. Effect of nandrolone and exercise on the accumulation of stress proteins (HSP72, HSP 73) in the left ventricle of rats. Equal amounts of proteins from the left ventricle of rats from the four groups were separated by SDS-PAGE and immunoblotted with a monoclonal HSP70 antibody. The animals were treated as described in the legend to Table $1 . \mathrm{NE}=$ nandrolone exercise; $\mathrm{CE}=$ control exercise; $\mathrm{NS}=$ nandrolone sedentary; $\mathrm{CS}=$ control sedentary. 
These results indicate that the heart of the exercised animals did adapt to the physiological overload imposed by the exercise program. The increase in the induction of cardiac expression of HSP72, a member of the stress-induced HSP70 protein family, may reflect the high intensity of the intracellular stress generated by the forced treadmill running regime. Indeed, increased cardiac HSP72 content has been observed in chronically exercised rats (16).

Although the use of an anabolic steroid caused serious injuries in the rodent heart $(2,3)$, the levels of HSP72 in cultured rat cardiac myocytes were not increased by $5 \alpha$ dihydrotestosterone (17). Knowlton and Sun (17) were unable to demonstrate the presence of androgen receptors in adult male cardiac myocytes, but other investigators have reported that androgen receptors are present in whole rat heart (18). Nonetheless, it was recently reported that castration inhibited exercise-induced accumulation of HSP70 in male rat hearts (19).

Our finding may mean that the nandrolone dose used ( $6.5 \mathrm{mg} / \mathrm{kg}$ body weight) was not sufficient to cause any deleterious ef- fects on the myocardium of these animals in 8 weeks. In fact, increased levels of HSP72 were reported in rat skeletal muscle in response to nandrolone administration for 8 weeks, but only by injecting higher doses (10 mg/kg body weight) (20). Likewise, the doses of nandrolone used in the present study may not have promoted sufficient intracellular stress to increase HSP72 expression.

The current study cannot address whether or not the administration of such doses of nandrolone promoted any injury to the rat heart. Nevertheless, the lower induction of HSP72 expression suggests a low intensity of the intracellular stress generated by nandrolone administration, which was not enough to increase the induction of HSP72 expression. On the other hand, if we admit that nandrolone administration caused some injury to the hearts of these animals, such lack of HSP72 accumulation could explain, at least in part, the deleterious effects of this synthetic hormonal agent on the myocardium observed by others $(2,3)$ inasmuch as protection of cardiac cells by HSP72 may not have occurred.

\section{References}

1. Celotti $F$, Negri CP. Anabolic steroids: a review of their effects on the muscles, of their possible mechanisms of action and of their use in athletics. J Steroid Biochem Mol Biol 1992; 43: 469-477.

2. Appell HJ, Heller-Umpfenbach B, Feraudi M, Weicker H. Ultrastructural and morphometric investigations on the effects of training and administration of anabolic steroids on the myocardium of guinea pigs. Int J Sports Med 1983; 4: 268-274.

3. Cavasin MA, Tao ZY, Yu AL, Yang XP. Testosterone enhances early cardiac remodeling after myocardial infarction, causing rupture and degrading cardiac function. Am J Physiol Heart Circ Physiol 2006; 290: H2043-H2050.

4. Crisostomo PR, Wang M, Wairiuko GM, Morrell ED, Meldrum DR. Brief exposure to exogenous testosterone increases death signaling and adversely affects myocardial function after ischemia. Am J Physiol Regul Integr Comp Physiol 2006; 290: R 1168-R 1174.

5. McNutt RA, Ferenchick GS, Kirlin PC, Hamlin NJ . Acute myocardial infarction in a 22-year-old world class weight lifter using anabolic steroids. Am J Cardiol 1988; 62: 164.
6. Kiang J G, Tsokos GC. Heat shock protein $70 \mathrm{kDa}$ : molecular biology, biochemistry, and physiology. Pharmacol Ther 1998; 80: 183201.

7. Atalay M, Oksala NK, Laaksonen DE, Khanna S, Nakao C, Lappalainen J, et al. Exercise training modulates heat shock protein response in diabetic rats. J Appl Physiol 2004; 97: 605-611.

8. Noble EG, Moraska A, Mazzeo RS, Roth DA, Olsson MC, Moore $R L$, et al. Differential expression of stress proteins in rat myocardium after free wheel or treadmill run training. J Appl Physiol 1999; 86: 1696-1701.

9. Chicco AJ, Schneider CM, Hayward R. Voluntary exercise protects against acute doxorubicin cardiotoxicity in the isolated perfused rat heart. Am J Physiol Regul Integr Comp Physiol 2005; 289: R 424R431.

10. Colégio Brasileiro de Experimentação Animal (COBEA). Princípios éticos na experimentação animal. (COBEA) http://www.cobea. org.br/etica; 1991.

11. Bradford MM. A rapid and sensitive method for the quantitation of 
microgram quantities of protein utilizing the principle of protein-dye binding. Anal Biochem 1976; 72: 248-254.

12. Laemmli UK. Cleavage of structural proteins during the assembly of the head of bacteriophage T4. Nature 1970; 227: 680-685.

13. Natali AJ, Wilson LA, Peckham M, Turner DL, Harrison SM, White E. Different regional effects of voluntary exercise on the mechanical and electrical properties of rat ventricular myocytes. J Physiol 2002; 541: 863-875.

14. Pescola MK. Reversibility of the haemodynamic effects of anabolic steroids in rats. Eur J Appl Physiol 1988; 58: 125-131.

15. Woodiwiss AJ , Trifunovic B, Philippides M, Norton GR. Effects of an androgenic steroid on exercise-induced cardiac remodeling in rats. J Appl Physiol 2000; 88: 409-415.

16. Paroo Z, Haist J V, Karmazyn M, Noble EG. Exercise improves postischemic cardiac function in males but not females: conse- quences of a novel sex-specific heat shock protein 70 response. Circ Res 2002; 90: 911-917.

17. Knowlton AA, Sun L. Heat-shock factor-1, steroid hormones, and regulation of heat-shock protein expression in the heart. Am J Physiol Heart Circ Physiol 2001; 280: H455-H464.

18. Sun L, Chang J, Kirchhoff SR, Knowlton AA. Activation of HSF and selective increase in heat-shock proteins by acute dexamethasone treatment. Am J Physiol Heart Circ Physiol 2000; 278: H1091H1097.

19. Milne KJ, Thorp DB, Melling CW, Noble EG. Castration inhibits exercise-induced accumulation of $\mathrm{Hsp70}$ in male rodent hearts. Am J Physiol Heart Circ Physiol 2006; 290: H1610-H1616.

20. Gonzalez B, Hernando R, Manso R. Anabolic steroid and genderdependent modulation of cytosolic HSP70s in fast- and slow-twitch skeletal muscle. J Steroid Biochem Mol Biol 2000; 74: 63-71. 